\title{
Az utánzás-alapú dimenzió megjelenése a közösségi kereskedés másolási döntéseiben
}

\author{
Papp Tamás - Erdös Sándor \\ Pécsi Tudományegyetem
}

\begin{abstract}
A TANULMÁNY CÉLJA
A tanulmány azt kívánja bemutatni, hogy miért szükséges a közösségi kereskedés hálózatát alkotó szereplök közötti bizalom kialakulásának duális felosztáson alapuló modelljeit, egy, az utánzó magatartáson alapuló dimenzióval kiegészíteni. Az új elméleti koncepcióval azt kívánjuk bemutatni, hogy a másolásra vonatkozó döntéshozatalra a szakirodalomban elfogadott kognitív-, és érzelmi-alapú jelzések mellett, az utánzás-alapú jelzéscsoportok is hatással vannak. Modellünk szerint a bizalom legerősebb formája a három dimenzió együttes megléte mellett valósul meg.
\end{abstract}

\section{ALKALMAZOTT MÓDSZERTAN}

A tanulmányban a koncepciónk alapjául szolgáló utánzó magatartáshoz kapcsolódó szakirodalmat, valamint a befektetési platformok között újnak számító közösségi kereskedés jellemzőit kívánjuk bemutatni a vonatkozó elméleti szakirodalom feltárásával. Ezt követően a közösségi kereskedés szereplöi között kialakuló bizalom magyarázatául szolgáló új koncepciónk kerül megfogalmazásra. A tanulmány végén röviden a modellünk érvényességének a bizonyításához létrehozott kísérleti tervet mutatjuk be.

\section{LEGFONTOSABB EREDMÉNYEK}

A közösségi kereskedéshez kapcsolódó tanulmányok a másolási döntés alapjául szolgáló bizalom kialakulását kognitív-, és érzelmi-alapú jelzésekre vezetik vissza. A pénzügyi befektetések során azonban a bizonytalanságcsökkentés igénye abban az esetben is fennmaradhat, ha minden szereplő számára korlátozás nélkül elérhetők e két dimenzióhoz kapcsolódó adatok. Az információs környezet még ebben az ideális esetben is aszimmetrikus, hiszen az adatforrás megbízhatóságát és hitelességét, valamint az információ minőségét és jelentőségét minden döntéshozónak magának kell megítélnie. A bizonytalanság csökkentésének egyik leghatékonyabb módja, ha a befektetők megfigyelik más befektetők döntéseit, azaz utánzó magatartást folytatnak. Ez érvényes a közösségi kereskedés során létrejövő döntési folyamatok esetében is, így a másolási döntés alapjául szolgáló bizalom kialakulását magyarázó duális modellt, egy harmadik új dimenzióval, az utánzás-alapú jelzésekkel egészítjük ki.

\section{GYAKORLATI JAVASLATOK}

A közösségi befektetésben a vezető befektetők portfóliójának másolására vonatkozó döntések vizsgálatát nem csak a vezető befektetők által küldött egyedi jelzések feldolgozására kell szúkíteni, hanem a közösség többi szereplője által küldött jelzésekre is szükséges kiterjeszteni. Ennek vizsgálatához egy kísérleti tervet mutatunk be, mellyel vizsgálható, hogy az utánzás-alapú dimenzió milyen szerepet tölt be a másolásra vonatkozó döntéshozatalban. A szisztematikusan összeállított kísérlet alkalmazásával, mely a közösségi kereskedés jellemzőit imitálja, bizonyítható, hogy a közösségi kereskedésben a másolásra vonatkozó döntési helyzeteket miként befolyásolják az egyes dimenziók.

Kulcsszavak: utánzó magatartás, bizalom, utánzás-alapú dimenzió, közösségi kereskedés, másolási kereskedés

DOI: 10.15170/MM.2021.55.KSZ.02.07 


\section{BEVEZETÉS INTRODUCTION}

Arisztotelésznek tulajdonítjuk a mondást: az ember utánzó lény. Az utánzó magatartás (herd behavior vagy herding), vagyis az a jelenség, hogy az emberek alkalmanként a rendelkezésükre álló információ által sugalltak ellenére másokat követve cselekednek (Banerjee 1992) jelentős kutatói erőforrásokat mozgósított a tudomány számos ágában. 300 évnyi kutatást átölelő összefoglalójában Raafat et al. (2009) azonosítja az utánzó magatartás vizsgálatát a közgazdaságtan, a pénzügy, a pszichológia, a szociológia, az etológia, az orvostudomány, a genetika és a politikai tudományok területén. Mint ahogyan az a tudományágakon átívelö témák esetében nem szokatlan, a jelenség pontos definíciójára nem alakult ki univerzálisan elfogadott konszenzus.

Az utánzó magatartást leíró elméleti modellek tipikusan (i) az egyének közötti kapcsolatok mintázata, vagy (ii) a befolyás mechanizmusa felöl közelítik meg a kérdést (Raafat et al. 2009). A kapcsolati háló szerepét elsősorban a kvantitatív eredményekben érdekelt közgazdaságtani kutatások hangsúlyozzák, míg a befolyás mechanizmusait, és kiváltó okait a humán tudományok a tapasztalati közgazdaságtannal karöltve igyekeznek kiismerni. A kutatás fenti két irányzata azonban nem független egymástól: Rook (2006) az utánzó magatartás eredményeinek történeti összefoglalójában a pszichológia, és a közgazdasági irányultságú megközelítések egymást ösztönző eredményeit hangsúlyozza.

A pénzügy területén a gazdasági válságok után, és következtében, érthető okokból negatív felhanggal erősödik fel a kutatói, és szakmai érdeklődés az utánzó magatartás iránt. Különösen a befektetők tevékenységének a vizsgálata bizonyul eredményesnek az utánzó magatartás azonosítására a viszonylag egyszerü akciók (vétel / eladás / pozíció tartása) és a piaci árak alakulása által jól dokumentálható következmények miatt. Ugyanakkor a piaci információk általánosan a befektetők rendelkezésére állnak, ezért nem feltétlenül egyértelmü, mi számít valódi utánzás-alapú döntésnek, és mi számít a közös impulzusból származó egyhangú, de egyéni értékelés alapján hozott döntések összegének (Bikhchandani \& Sharma, 2000). A kutatások az utánzó magatartást a befektetői döntések minden formájára jellemzőnek találták. Viszonylag egyszerüen észrevehető az utánzás, és a racionalitás hiánya az elterjedt momentum-befektetői stratégiában, ami az eszközök múltbeli trendjére alapozza a vételi és eladási döntéseket. Jól példázza ez a követő magatartás korlátozott racionalitását, ugyanis a hatékony piacok elmélete szerint az eszközök mindenkori ára minden elérhető információt tartalmaz, így ez alapján befektetési döntést hozni nem más, mint a tapasztalható piaci konszenzus követése.

Az utánzó magatartás kérdésének modern aktualitása nem független a viselkedési közgazdaságtan elméletének elterjedésétől. Koltay és Vincze (2009) szerint a viselkedési közgazdaságtan nem ellentétes a klasszikus és neoklasszikus közgazdaságtan elméletével, sokkal inkább annak természetes továbbfejlesztése. Bár a neoklasszikus és a viselkedési közgazdaságtan közel azonos matematikai módszertanra, és összefüggésbeli elemekböl építkezik, az utóbbi erősebben támaszkodik a valós élethelyzetek megfigyelésére, és a kísérleti közgazdaságtan módszertanára, a hagyományos megközelítés szinte abszurd módon idealizált, steril feltételei helyett. Így a viselkedési közgazdaságtan nem feltételezi a döntéshozó tökéletes informáltságát és tökéletes racionalitását, sem a tökéletes piaci versenyt, vagy a társadalmi és egyéni hasznosság azonosságát, de nem szakad el attól a feltételezéstől, hogy a döntéshozók személyes hasznuk maximalizálására törekednek. A két megközelítés különbségei röviden úgy foglalhatók össze, hogy a klasszikus közgazdaságtan elméleti eredményeit a viselkedési közgazdaságtan valóságos környezetben figyeli meg, és ilyen körülmények között alkalmazza. Bár a neoklasszikus közgazdaságtan tisztán racionális megközelítésének védelmében elhangzik, hogy (i) az egyszerüsítés a világ komplexitása miatt a megértés érdekében elengedhetetlen, (ii) a valódi környezet szelekciója a racionalitást jutalmazza, (iii) és a megfigyelt egyéni tévedések kioltják egymást, normatívájának alkalmazását az egyéni döntések szubjektív elemei nehezítik.

Elsőként a Simon (1955) által megfogalmazott korlátozott racionalitás elve ajánlott keretet a viselkedési közgazdaságtan számára. A korlátozott racionalitás figyelembe veszi, hogy az egyéni döntések hatékonyságát csökkenti a rendelkezésre álló információ nem teljes mennyisége, az adatfeldolgozásra áldozható kapacitás véges volta, valamint a döntéshozó figyelmének tökéletlensége. E nehézségek miatt a döntések célja a korlátozott racionalitás elve szerint nem az ideális, hanem a döntéshozó számára kielégítő eredmény elérése. A neoklasszikus idealizmus másik akadálya az emberi pszichében keresendő, amit a szociális nyomás, a döntéshozó esendősége és a kockázathoz való hozzáállás egyéni jellemzői okoznak (Kahneman \& Tversky 1979, Tversky \& Kahneman 1992). Koltay és Vincze (2009) idézetében Rabin (1998) ehhez hozzáteszi, hogy az egyéni döntések nem abszolút és semleges információs térben, valamint időtálló 
preferenciák mentén keletkeznek, hanem referencia-pontok viszonylátában, a szociális kapcsolatrendszer viszonyai között és időlegesen érvényes elvárások mentén.

A következökben a befektetési platformok között újnak számító közösségi kereskedés jellemzői kerülnek bemutatásra, mely szereplői között létrejövő bizalom kialakulását magyarázó elméleti modellt mutatjuk be. Ezt követően új koncepciónkat vázoljuk fel, mely az uralkodó modellek duális felosztását egészíti ki, egy az utánzó magatartáson alapuló dimenzióval. Végül a modellünk érvényességének a bizonyításához létrehozott kísérleti tervet mutatjuk be röviden.

\section{A KÖZÖSSÉGI KERESKEDÉS JELLEMZŐI CHARACTERISTICS OF SOCIAL TRADING}

Az utóbbi években a legújabb pénzügyi technológiák nagyban átformálták azt, ahogy a kisbefektetők belépnek a pénzügyi piacokra. A közösségi kereskedés, mely a közösségi média és az online kereskedés innovatív kombinációja, lehetővé tette a felhasználók számára, hogy egy új környezetben kereskedjenek értékpapírokkal, devizapárokkal, illetve egyéb pénzügyi eszközökkel. Tekintve a jelenlegi erős trendet a pénzügyi szolgáltatások dezintermediációja felé - például közösségi finanszírozás, peer-to-peer hitelezés - a közösségi befektetés a konvencionális eszközkezelői szolgáltatások potenciális kihívója (Doering et al. 2013).

Ezek az innovatív online felületek a tradicionális kereskedési jellemzőkön túl, a közösségi média jellemzőit hordozzák. Lehetővé teszik, hogy a felhasználók folyamatosan nyomon kövessék egymás kereskedési döntéseit, stratégiáit, múltbeli teljesítményét, valamint aktuális portfólióját valós időben, mindezt úgy, hogy közben a közösségi médiához hasonlóan alakíthatják saját profiljukat és léphetnek kapcsolatba mással a hálózaton belül. A transzparencia magas szintje, valamint az alacsony belépési korlátok nagyszámú kisbefektetőt vonzottak a közösségi kereskedés irányába (Gemayel \& Preda 2018a). A különböző platformok rendkívül gyorsan fejlődnek, így nem csak egymástól térnek el a nyújtott szolgáltatások tekintetében, hanem sokat változik megjelenésük és nyújtott szolgáltatásaik köre is.

Amiben a közösségi kereskedési platformok a leginkább különböznek a tradicionális felületektöl, hogy lehetővé teszik a felhasználók számára mások befektetési döntéseinek másolását. Ez azt jelenti, hogy az egyéni befektetőnek nem szükséges az elérhető pénzügyi termékeket elemeznie. Elegendő találnia egy számára szimpatikus befektetőt, akinek teljes portfólióját, vagy portfóliójának egyes elemeit egyszerủen, valós időben és költségmentesen lemásolja. Ez a funkció lehetőséget biztosít a kevésbé tapasztalt befektetők számára, hogy jobb eredményeket érjenek el annál, mintha önállóan hozták volna meg befektetési döntéseiket (Pan et al. 2012, Oehler et al. 2016).

A közösségi kereskedés olyan hálózatot alakít ki, melyben az másoló kereskedés (copy trading) egy egyedülálló és egyre népszerübb lehetőség (Wohlgemuth et al. 2016). Ebben a hálózatban a legtágabb felbontásban két csoport különíthető el: (i) a tapasztaltabb befektetők, akik befektetési döntéseiket önállóan hozzák meg, és akik kompenzációban részesülnek, attól függően, hogy mely tevékenységet értékeli az adott kereskedési felület. Öket a szakirodalom a vezető kereskedő névvel illeti (Gemayel \& Preda 2018a, 2018b, Pelster \& Hofmann 2018). (ii) Másik nagy csoportot azok a befektetők alkotják, akik előbbi csoport döntéseit másolják, vagy automatikusan a lemásolt befektető összes jövőbeni kereskedésére vonatkozóan, vagy portfóliójának egyes elemeit manuálisan kiválasztva. Utóbbiak - másoló befektetők - képesek portfóliójuk diverzifikálására azáltal, hogy eltérő stratégiával rendelkező, különböző kockázati besorolású vezető kereskedőt választanak másolásra (Gemayel \& Preda 2018b). Habár némi fogalmi hasonlóság felfedezhető a tradicionális eszközkezelés és a közösségi kereskedés között, abban az értelemben, hogy az utánzók befektetésre váró tőkéjüket a vezető kereskedők stratégiájába fektetik, itt a kapcsolat a két csoport között informális, mivel elöbbi bármikor eltérhet az általa kijelölt stratégiától, és nem terheli szankció, ha rossz döntése negatív következményekkel jár.

\section{UTÁNZÁS-ALAPÚ DIMENZIÓ HERD-BASED DIMENSION}

A közösségi befektetést érintő korai tanulmányok olyan elemzésekre korlátozódtak, melyek az új kereskedési környezetben a befektetők profittermelési képességeit vizsgálták (Oehler et al. 2016), valamint a felhasználók közzétett értékelései, és az értékelés alapjául szolgáló eszközök jövőbeni hozama közötti kapcsolatot tárták fel (Breitmayer et al. 2019). Köszönhetően a befektetők közötti kapcsolati hálók transzparenciájának, valamint az egymás közötti kommunikáció elérhetöségének a későbbi kutatások a társadalmi tényezők befolyását is képesek voltak vizsgálni, különösen azt, hogy 
milyen tényezők játszanak szerepet a másolásra kijelölt befektető kiválasztásában (Pan et al. 2012, Wohlgemuth et al. 2016, Pelster 2018, 2019, Kromidha \& Li 2019, Röder \& Walter 2019).

$\mathrm{Az}$ eddigi tanulmányok arra a feltételezésre támaszkodtak, hogy a bizalom központi szerepet tölt be a másolás kialakulásában, és a vezető befektetők által küldött jelzésekből építkezik (Roca et al. 2009, Wohlgemuth et al. 2016, Kromidha \& Li 2019). A bizalom egy pszichológiai állapot, amely magában foglalja a sebezhetőség elfogadásának hajlandóságát, egy másik féltől várt pozitív cselekvési szándék vagy magatartás alapján (McAllister 1995). A bizalom és ezáltal a másolás tehát akkor valósul meg, ha a vezető kereskedők által adott jelzések a megbízhatóságot, hitelességet reflektálják. A közösségi kereskedéshez kapcsolódó tanulmányok, másolókban kialakuló bizalmat magyarázó modelljei a megbízhatósági jelzések duális felosztását vették alapul (Wohlgemuth et al. 2016, Kromidha \& Li 2019). E szerint a megbízhatóságot sugalló és bizalmat felépítő jelzések két csoportra oszthatók: kognitív-alapú, illetve érzelmi-alapú jelzések. Előbbi jelzések arról nyújtanak információt, hogy az, aki felé a bizalom irányul, mennyire kompetens a területspecifikus feladatokat illetően. Utóbbi jelzések azt mutatják, hogy a két fél által osztott értékek mennyire egyeznek, valamint az, aki felé a bizalom irányul, mennyire öncélú (Wohlgemuth et al. 2016). A közösségi kereskedés esetében a vezető befektetők kiválasztásakor a kognitív-alapú jelzések a profitábilis befektetési döntéseket reflektáló változókra - például adott periódus alatt elért hozam, profitábilis ügyletek aránya, kockázati besorolás stb. - vonatkozhatnak, míg az érzelmi-alapú jelzések a közösségi hálózattal történő interakciók gyakoriságát, a teljes név, illetve az arckép felfedését jelenthetik (Wohlgemuth et al. 2016).

Nem szabad elfelejteni azonban, hogy az utánzó magatartás kiváltó okai között kifejezetten nagy szerepet játszanak a jelzések terjedésének és értelmezésének kérdései. Habár a kognitív-, és érzelmi-alapú jelzések a bizalom kialakulásában fontos szerepet töltenek be (Wohlgemuth et al. 2016, Kromidha \& Li 2019) a bizonytalanságcsökkentés igénye abban az esetben is fennmaradhat, ha mindkét jelzéscsoport rendelkezésre áll. Ez a gazdaság minden olyan területére érvényes, ahol a folyamatok gyorsan és kiszámíthatatlanul változnak, és ahol a döntések eredményei csak késleltetetten jelentkeznek. Ide tartozik többek között a pénzügyi befektetések piaca, és azon belül a közösségi kereskedés is. A pénzügyi befektetések piacának megfigyelése után Bikhchandani és Sharma (2001) arra a következtetésre jutottak, hogy a bizonytalanság csökkentését célzó információgyüjtés leghatékonyabb módja, ha megfigyeljük más befektetők döntéseit is, és így következtetünk a számunkra rendelkezésre álló teljes információbázisra alapozva. A szerzők szerint a pénzügyi piacok esetében még abban az esetben is beindul az utánzó magatartás, amikor minden szereplő számára korlátozás nélkül elérhetőek az optimális döntéshozatalhoz szükséges adatok. Az információs környezet még ebben az ideális esetben is aszimmetrikus, hiszen az adatforrás megbízhatóságát és hitelességét, valamint az információ minőségét és jelentőségét minden döntéshozónak magának kell megítélnie, ami azonban privát információnak minősíthető. E szerint mások befektetési döntései még tökéletes informáltság mellett is tartalmaznak személyes elemeket, amire leghatékonyabban a publikus befektetési döntések alapján lehet következtetni, és a másolásuk észszerü stratégia. Sőt, az utánzó magatartás még abban az esetben is előállhat, ha kellő számú ellentétes véleményt látva a befektető, vállalva a kognitív konfliktust saját ítéletével, privát értékelését figyelmen kívül hagyja. Ha így tesz, növelheti a saját befektetésének potenciális hozamát, viszont a befektető saját privát információja elveszik a további utánzó magatartást követő szereplő számára.

A fentiek a közösségi kereskedésben a másolásra vonatkozó döntést illetően is érvényesek, hiszen önmagában a vezető befektető kiválasztása is egy befektetési döntésnek tekinthető. Ebben az esetben az információgyüjtés nem az értékpapírokra irányul, hanem azon vezető befektetőkre, akiket a másolók vonzónak találnak. Véleményünk szerint a kognitív-, és érzelmi-alapú jelzések teljes megléte mellett is fennmarad egy bizonyos mértékü bizonytalanság a döntéshozatalban, melynek eliminálása a legtöbb befektető esetében igényként jelentkezik. Ez a bizonytalanság mások döntésének a megfigyelésével redukálható tovább, ami jelen kontextusban a vezető befektetőt már másoló befektetők számának megfigyelésével érhető el (ez az információ a közösségi kereskedés transzparens hálózatában rendelkezésre áll). Véleményünk szerint, ha erre az információra alapozva hozza meg döntését a befektető, akkor utánzó magatartást tanúsít. Mivel a másoló befektetők megfigyelése utánzó magatartást válthat ki, ezért ezen jelzéseket utánzás-alapú jelzésekként definiáltuk. A bizalom kialakulásához a bizonytalanság megfelelő szintre történő redukálása elengedhetetlen, valamint a másolási döntés meghozatalához a bizalom létrejötte szükséges (Roca et al. 2016, Wohlgemuth et al. 2016, Kromidha \& Li 2019), ezért azt feltételezzük, hogy a bizalom kialakulásában és a másolásra vonatkozó 
döntés meghozatalában a kognitív-alapú, és érzelmi-alapú jelzések mellett, az utánzás-alapú jelzések is szerepet játszanak. Habár a vezető befektetők felé irányuló bizalom kialakulásának nem szükséges feltétele a jelzéscsoportok együttes megléte, feltételezésünk szerint a bizalom akkor a legerősebb, valamint a másolás abban az esetben jön létre a legnagyobb valószínüséggel, ha mindhárom dimenzió jelen van (1. ábra). A pénzügyi döntések során már bizonyított tény, hogy az utánzó magatartásnak hatása van a döntéshozatal folyamatára, véleményünk szerint a közösségi kereskedésben a másolásra vonatkozó döntések tekintetében is befolyásoló erővel bír az utánzó-alapú dimenzió megjelenése.

\section{1. ábra: A bizalom kialakulását megalapozó jelzéscsoportok}

Figure 1. Signaling groups that build trust

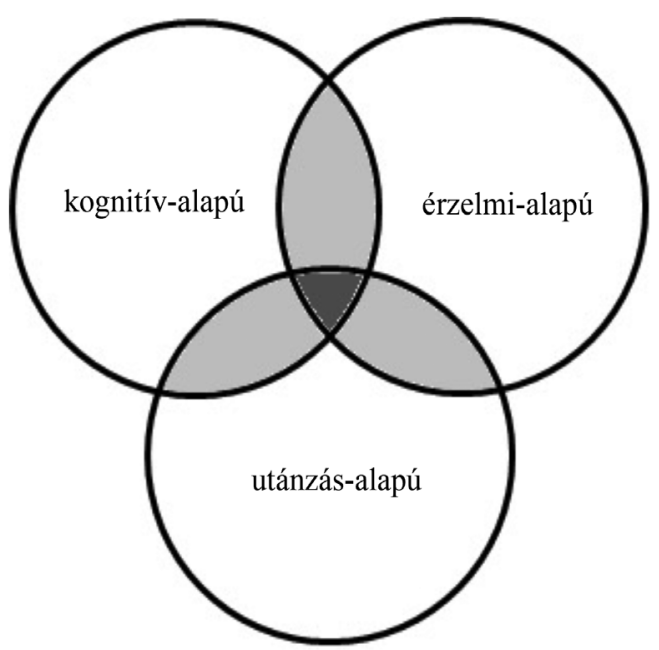

Megjegyzés: A világos szürke területek azt jelzik, ahol a bizalom, és így a másolás kialakulhat, a sötétszürke terület esetén a bizalom a legerösebb.

Forrás: Saját szerkesztés

\section{UTÁNZÓ-ALAPÚ DIMENZIÓ DÖNTÉSBEFOLYÁSOLÓ HATÁ- SÁNAK TERVEZETT KÍSÉRLETE PLANNED EXPERIMENT OF THE INFLUENCE OF HERD-BA- SED DIMENSION ON DECISION MAKING}

A utánzás-alapú dimenzió döntésbefolyásoló meglétét a közösségi kereskedés jellemzőit szimuláló, szisztematikusan összeállított kísérlet során kívánjuk bizonyítani, a döntéhozók befektetési döntéseire alapozva. A tervezett kísérlet során a döntéshozó másolási döntést hoz, kettő, a vezető befektetőre vonatkozó jelzéscsoportok adatainak összehason- lítása alapján. A kísérlet első felében a megbízhatósági jelzések duális felosztása alapján a vezető befektetőkröl kognitív-, és érzelmi-alapú információkat osztunk meg a döntéshozóval, melyekkel igazolni kívánjuk a közösségi kereskedés másolási döntéseire vonatkozó modellek eredményeit (Wohlgemuth et al. 2016, Kromidha \& Li 2019). A kísérlet folytatásaként megjelenítjük az előbb említett két dimenzió mellett a vezető befektető, utánzás-alapú dimenziójához tartozó értékeit is a döntéshozó számára. Mindegyik dimenzió jó vagy rossz minősítéssel rendelkezik, melyek a döntéhozó számára egyértelműen értelmezhetően kerülnek megjelenítésre. Az előbb említett dimenzók előre meghatározott minősítéseinek variánsaival kívánjuk bizonyítani az utánzó-alapú dimenzió 
döntésbefolyásoló szerepét a döntéshozók másolási döntéseinek meghozatalánál, melyet a kísérlet során létrejövő információhalmaz elemzésével kívánunk igazolni.

\section{ZÁRÓ GONDOLATOK CONCLUDING REMARKS}

Jelen tanulmány a közösségi kereskedés hálózatát alkotó szereplők interakcióit magyarázó tanulmányokhoz kapcsolódik. A fentiekben azt a kérdést jártuk körül, hogy milyen jelzések befolyásolják a másoló befektetők döntéseit, amikor másolási döntéseiket hozzák meg (ti. a közösségi kereskedés lehetővé teszi, hogy a másoló befektetők a vezető befektetők összes jövőbeni kereskedési döntését automatikusan, vagy a portfóliójuk egyes elemeit manuálisan kiválasztva lemásolják). A tanulmányban bemutattuk új koncepciónkat, mely a másolási döntések kialakulásának magyarázatául szolgáló modellt az utánzó magatartás dimenziójával egészíti ki. Az utánzó magatartás jelentős kutatói erőforrást mozgosított mind a közgazdaságtudomány, mind a pszichológia területén egyaránt, és nem hagyta érintetlenül a pénzügy területét sem. Az utánzó magatartás egy általános jelenség, melyet a bizonytalanság csökkentésének igénye hív életre, és amely a gazdaság minden olyan területén jelen lehet, ahol a folyamatok gyorsan változnak, valamint ahol a döntések eredményei csak késleltetetten jelentkeznek (Rook 2006). Ilyen terület a közösségi kereskedés is, mely a közösségi média és az online kereskedés innovatív kombinációja, és amely lehetővé teszi a felhasználók számára, hogy egy új környezetben kereskedjenek értékpapírokkal, devizapárokkal, illetve egyéb pénzügyi eszközökkel.

A közösségi kereskedés hálózatát alkotó szereplők - vezető és másoló befektetők - döntéseit vizsgáló tanulmányok egyik iránya a másolási döntések alapjául szolgáló bizalom kialakulását vizsgálja. Az ide kapcsolódó tanulmányok, másolókban kialakuló bizalmat magyarázó modelljei, a megbízhatósági jelzések duális felosztását vették alapul. E szerint, a megbízhatóságot sugalló és bizalmat felépítő jelzések két csoportra oszthatók: kognitív-alapú, illetve érzelmi-alapú jelzések (Wohlgemuth et al. 2016, Kromidha \& Li 2019). Koncepciónk, mely szerint a vezető befektetők által küldött kognitív-, és érzelmi-alapú jelzéseket, a közösség tagjai által küldött jelzésekkel - utánzás-alapú jelzések - szükséges kiegészíteni, az utánzó magatartás jelenségére támaszkodik. Azzal a feltételezéssel élünk tehát, hogy a döntéshozó a bizonytalanságcsökkentés érdekében, nem csak a vezető befektetőre vonatkozó jelzéseket veszi figyelembe, hanem a közösség döntéseit, preferenciáit is mérlegeli, és erre az információhalmazra támaszkodva hoz döntést arra vonatkozóan, hogy kit választ másolásra. Az utánzó magatartás, tehát a többség döntésének a követése, a másolási döntésekben is befolyásoló szereppel bír. Úgy véljük, hogy a bizalom akkor a legerősebb, így a másolás abban az esetben jön létre a legnagyobb valószínűséggel, ha mindhárom jelzéscsoport jelen van - kognitív-, érzelmi-, és utánzás-alapú. Új elméleti koncepciónk relevanciája abban mutatkozik meg, hogy kiegészíti a közösségi kereskedés szereplői közötti kapcsolatok dinamikájával foglalkozó elméletet, alapot adva így a jelenséggel foglalkozó munkák kiterjedtebb vizsgálatának. Emellett iránymutatásul szolgál az empirikus munkák számára, hogy mely dimenziók mentén érdemes a másolási döntéseket vizsgálni annak érdekében, hogy ezek a döntések teljes mértékben megismerhetővé váljanak. Az utánzás-alapú jelzések fontosságának alátámasztásául egy rövid kísérleti tervet mutattunk be, mely a későbbi empirikus kutatások alapjául szolgálhat. 


\section{HIVATKOZÁSOK REFERENCES}

Banerjee, A. V. (1992), "A simple model of herd behavior", The Quarterly Journal of Economics, 107(3), 797-817 DOI: 10.2307/2118364

Bikhchandani, S. \& Sharma, S. (2000), "Herd behavior in financial markets: A Review", IMF Staff Papers, No. 00/48 DOI: 10.5089/9781451846737.001

Breitmayer, B., Massari, F. \& Pelster, M. (2019), "Swarm intelligence? Stock opinions of the crowd és stock returns", International Review of Economics és Finance, 64, 443-464 DOI: 10.1016/j.iref.2019.08.006

Doering, P., Neumann, S. \& Paul, S. (2013), “A Primer on Social Trading Networks - Institutional Aspects and Empirical Evidence", SSRN, DOI: $10.2139 / \mathrm{ssrn} .2291421$.

Koltay, G., Vincze, J. (2009), „Fogyasztói döntések a viselkedési közgazdaságtan szemszögéböl", Közgazdasági Szemle, 56 (június), 495-525

Gemayel, R. \& Preda, A. (2018a), "Does a scopic regime erode the disposition effect? Evidence from a social trading platform", Journal of Economic Behavior and Organization, 154, 175190 DOI: 10.1016/j.jebo.2018.08.014

Gemayel, R. \& Preda, A. (2018b), "Does a scopic regime produce conformism? Herding behavior among trade leaders on social trading platforms", European Journal of Finance, 24(14), 11441175 DOI: $10.1080 / 1351847 X .2017 .1405832$

Kahneman, D. \& Tversky, A. (1979), "Prospect Theory: An Analysis of Decision under Risk", Econometrica, 47(2), 263-292 DOI: 10.1017/ CBO9780511803475.003.

Kromidha, E. \& Li, M. C. (2019), "Determinants of leadership in online social trading: A signaling theory perspective", Journal of Business Research, 97, 184-197 DOI: 10.1016/j.jbusres.2019.01.004

McAllister, D. J. (1995), "Affect- and cognition-based trust as foundations for interpersonal cooperation in organizations", Academy of Management Journal, 38(1), 24-59 DOI: $10.2307 / 256727$

Oehler, A., Horn, M. \& Wendt, S. (2016), "Benefits from social trading? Empirical evidence for certificates on wikifolios", International Review of Financial Analysis, 46, 202-210 DOI: 10.1016/j.irfa.2016.05.007

Pan, W., Altshuler, Y. \& Pentland, A. (2012), "Decoding social influence és the wisdom of the crowd in financial trading network", in
Proceedings - 2012 ASE/IEEE International Conference on Privacy, Security, Risk és Trust és 2012 ASE/IEEE International Conference on Social Computing, SocialCom/PASSAT 2012, DOI: 10.1109/SocialCom-PASSAT.2012.133

Pelster, M. (2018), “,I”ll Have What S/he's Having: A Case Study of a Social Trading Network", in ICIS 2017: Transforming Society with Digital Innovation, DOI: 10.2139/ssrn.2973194

Pelster, M. (2019), "Attracting attention from peers: Excitement in social trading", Journal of Economic Behavior és Organization, 161, 158179 DOI: $10.1016 /$ j.jebo.2019.03.010

Pelster, M. \& Hofmann, A. (2018), "About the fear of reputational loss: Social trading és the disposition effect", Journal of Banking és Finance, 94, 75-88 DOI: 10.1016/j.jbankfin.2018.07.003

Raafat, R. M., Chater, N. \& Frith, C. (2009), "Corrigendum: Herding in humans", Trends in Cognitive Sciences, 13, 420-428 DOI: 10.1016/j. tics.2009.10.001

Rabin, M. (1998), "Psychology és Economics", Journal of Economic Literature, 36(1), 11-46 DOI: $10.1057 / 9780230226203.3356$

Roca, J. C., García, J. J. \& de la Vega, J. J. (2009), "The importance of perceived trust, security és privacy in online trading systems", Information Management és Computer Security, 17(2), 96-113 DOI: 10.1108/0968522091096398

Röder, F. \& Walter, A. (2019), "What drives investment flows into social trading portfolios?", Journal of Financial Research, 42(2), 383-411 DOI: $10.1111 /$ jfir. 12174

Rook, L. (2006), "An economic psychological approach to herd behavior", Journal of Economic Issues. 40(1), 75-95 DOI: 10.1080/00213624.2006.11506883

Simon, H. A. (1955), "A behavioral model of rational choice", Quarterly Journal of Economics, 69(1), 99-118 DOI: 10.2307/1884852

Tversky, A. \& Kahneman, D. (1992), “Advances in prospect theory: Cumulative representation of uncertainty", Journal of Risk és Uncertainty, 5(4), 297-323 DOI: 10.1007/BF00122574

Wohlgemuth, V., Berger, E. S. C. \& Wenzel, M. (2016), "More than just financial performance: Trusting investors in social trading", Journal of Business Research, 69(11), 4970-4974 DOI: 10.1016/j.jbusres.2016.04.061 
Papp Tamás, PhD hallgató papp.tamas@ktk.pte.hu

Erdős Sándor, PhD hallgató erdos.sandor@ktk.pte.hu

Pécsi Tudományegyetem Közgazdaságtudományi Kar

\section{The role of herd-based dimension in the decision making of copy trading}

\section{THE AIMS OF THE PAPER}

The study intends to show why it is necessary to supplement the models of trust built between actors in the social trading network based on a dual division with a dimension based on imitative behavior. With the new theoretical concept, we would like to prove that in addition to the cognitive and emotional-based signals accepted in the literature, imitation-based signalling groups also have an impact on copying decision-making. According to our model, the strongest form of trust is realized with the coexistence of the three dimensions.

\section{METHODOLOGY}

In this study, we aim to present the literature related to the herd behaviour underlying our concept, as well as the characteristics of new social trading between investment platforms, by exploring the relevant theoretical literature. Following this, a new concept will be formulated to explain the trust that is being developed between the actors in social trading. At the end of the study, we present an experimental design created to demonstrate the validity of our model.

\section{MOST IMPORTANT RESULTS}

Studies related to social trading trace the development of trust that underlies the decision to copy back to cognitive and emotional signals. However, in the case of financial investments, the need to reduce uncertainty may persist even if data related to these two dimensions are available to all actors without restriction. Even in this ideal case, the information environment is asymmetric, as the reliability and authenticity of the data source, as well as the quality and relevance of the information, have to be judged by each decision-maker. One of the most effective ways to reduce uncertainty is for investors to monitor the decisions of other investors. This also applies to copying decisions in social trading, so we are adding a third new dimension to herd-based signalling to explain the development of trust that underpins copying decisions.

\section{RECOMMENDATIONS}

The examination of decisions to copy the portfolio of leaders in social trading should not be limited to the processing of individual signals sent by leaders, but should also be extended to signals sent by other actors in the community. In order to investigate this, we intend to present an experimental plan to investigate the role of the herd-based dimension in copying decision-making. Using a systematically designed experiment that mimics the characteristics of social trading, it can be demonstrated how copying decision-making situations in social trading are affected by each dimension.

Keywords: herd behavior, trust, herd-based dimension, social trading, copy trading 